Filipe CARREIRA DA SILVA, Mead and Modernity. Science, Selfhood and Democratic Politics

Lanham, Lexington Books, 2008

Anna M. Nieddu

\title{
CpenEdition
}

Electronic version

URL: http://journals.openedition.org/ejpap/856

DOI: 10.4000/ejpap.856

ISSN: 2036-4091

Publisher

Associazione Pragma

Electronic reference

Anna M. Nieddu, «Filipe carreira da SILva, Mead and Modernity. Science, Selfhood and Democratic Politics », European Journal of Pragmatism and American Philosophy [Online], III-2 | 2011, Online since 29 December 2011, connection on 24 September 2020. URL : http://journals.openedition.org/ejpap/856 DOI : https://doi.org/10.4000/ejpap.856

This text was automatically generated on 24 September 2020.

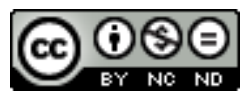

Author retains copyright and grants the European Journal of Pragmatism and American Philosophy right of first publication with the work simultaneously licensed under a Creative Commons AttributionNonCommercial-NoDerivatives 4.0 International License. 


\section{Filipe CARREIRA DA SILVA, Mead and Modernity. Science, Selfhood and Democratic Politics}

Lanham, Lexington Books, 2008

Anna M. Nieddu

\section{REFERENCES}

Filipe CARREIRA DA SILVA, Mead and Modernity. Science, Selfhood and Democratic Politics, Lanham, Lexington Books, 2008

\section{George H. Mead: A Therapy for the Malaise of Modernity?}

1 In his recent volume on Mead, Filipe Carreira da Silva proposes an interpretation of the pragmatist's thought that develops through three fundamental points of reference. According to the author, science, selfhood and democratic politics constitute "the pillars" of a new approach to the problem of modernity; an approach in which the mutual interchange between these moments projects on the theoretical level a reflection of the relational dynamics exerted by human beings through their language and their historical evolution. The interchange among these pillars foresees the development of a sort of logical progression whose key passages consist of the glide of these moments from the one to the other. Carreira da Silva maintains that the approach to modernity expressed by Mead's social theory can offer more than one well-grounded answer to the problems of our time. With reference to this problematic area, Charles Taylor's diagnosis could be the right term of comparison, even if in Carreira da Silva's work Taylor's positions remain in the background. So we could ask to ourselves if and in which ways an effective therapy to the discomforts of our 
modernity would be carried out through Mead's suggestions, as it seems possible to hold through this book.

\section{"The Making of a Classic"}

2 From the research of Carreira da Silva emerges a framework capable to give back authenticity to the thought of the pragmatist without sacrificing its depth and its wealth of articulations. Also because of the outwardly fragmentary character of his works, in fact, the destiny of the theoretical reflection of George H. Mead has often coincided with a restrictive use of his seminal suggestions. According to Carreira da Silva, this happens especially in the approach of H. Blumer to the meadian theory of social act. ${ }^{1}$ In Blumer's approach to Mead, Carreira da Silva recognizes: "an almost undistinguishable presentation of his own thought and Mead's ideas" (51). To build his interactionist perspective, Blumer would have used Mead's theory of social action only to develop an alternative to Parsons' structural functionalism. This required a sort of canonization of Mead in the sociological field (Part I, Chap. 4: The Making of a Classic, 49-62). This process of canonization, consolidating the fragmentary character of Mead's work, really accented the sectorial way of the approach to Mead by such an authoritative interpreter. That way, in fact, was not always unaware, and sometimes instrumental.

Carreira da Silva recognizes the presence in Habermas of an intent similar to that carried into effect by Blumer and points out that the two readings of Mead, despite the differences of method and results, are correlated among them and converge toward a same direction: “Habermas's criticism of Mead's alleged 'idealistic deviation' is very much in line with the widespread belief that Blumer's symbolic interactionism, due to Mead's influence, is incapable of dealing with large-scale structural social phenomena" (55; 151-62). In Habermas' Theorie des kommunikativen Handelns, ${ }^{2}$ Mead's suggestions become an useful tool to argue the author's thesis, but the way according to which the social theory of the pragmatist is reconstructed "is directly linked to the theoretical objectives of the social scientist who reconstructs it." In the case of Habermas "Mead's thinking is reconstructed so that the linguistic turn suffered by philosophy in the 1960's can be expanded to sociology through a paradigm shift-from purposive or instrumental action to comunicative action" (54).

\section{Restoring Mead's Profile}

The formulation of the leading problem of Carreira da Silva's volume directly feels the effects of these preliminary notations addressed towards two great interpreters of Mead that became 'classics' in their turn. Particularly, towards Habermas and his School (especially Axel Honneth) it would burden the result of an interpretative run that to Carreira da Silva appears forced, that is, the aim to reach Mead passing through Hegel (the first philosopher who - according to Habermas - put modernity in terms of a problem). What Carreira da Silva wants to show, in the first place, is that in wide measure the problem of modernity in Mead sets aside from any premise of idealistic character and constitutes itself around the three great moments of the evolutionistic science, the genesis and value of individuality, the opportunity to constitute a democratic society on these bases. In substance, what makes the notion of modernity 
transmitted by the thought of Mead particularly incisive is its capability to answer to the problematic situations of the present in a direct way. The expectations that Carreira da Silva deposes in Mead's reading lean on these results and, on the basis of these results, the pragmatist can really be considered a classic. Nevertheless, a classic must be respected such as a classic and his thought must be contextualized; therefore, the meanings of Mead's social theory must be understood for what they represented in the frame of the society of his time. So, if it is right to depart from the likeness between the critical situation of our time and Mead's historical epoch for grounding the great relevance to the present of his thought, nevertheless the researcher is not allowed to make Mead's theory up-to-date, neither to level different historical times upon a same judgment, flattening them. On this plan, the results of the work of Carreira da Silva fall into line with those expressed in the best tradition of studies on Mead. ${ }^{3}$

\section{Mind, Self, Society, and Beyond}

This book by Carreira da Silva not only contributes to a best knowledge of the thought of Mead, but really shows that a philological approach to the text, not enslaved to mere erudition, is the only approach that allows a 'productive' relationship with its author. A relationship that is capable to gather Mead's approach to modernity without updating his thought or distorting the sense of his message. On a philological plane, Carreira da Silva handles his subject with the utmost exactitude by means of a careful examination of the sources, published and unpublished. In this way, he disavows the historiographic skepticism traditionally related to Mind Self and Society and shows that Mead's text does not lean on improvised connections among notes of students but is founded on the shorthand work of professionals. The reasons for Mead's ransom from the theoretical cages in which he has been situated by a conspicuous part of his interpreters primarily send the attention back to this book. Truly it represents a fundamental starting point, since it literally sets the foundations of an even more articulated and complex approach to the problem of reality. On this matter, it is worth to remember the pioneering judgment of David Victoroff that, in 1953, already opened a breach in the compact front of Mead's scholars warning that the pragmatist was not to consider only "a sociologist," but rightfully "a philosopher."

The Philosophy of the Act and the Philosophy of the Present, broadly considered in order to the expansion of social problems in a cosmological sense, still attend to be investigated through a key of reading able to enucleate the connected philosophical implications relating to the transformations of science and to their ethical and political relapses. It could be interesting to examine, in fact, if Mead's lesson relating to a renewed plan of understanding of the extended dynamics between individuality and sociality could still open a new, fruitful way to put the basis of democratic politics and to recognize the more incisive 'productivity' of joint and several liability relations between human beings. 


\section{BIBLIOGRAPHY}

BLUMER H., (1969), Symbolic Interactionism: Perspective and Method, Berkeley, University of California Press.

HABERMAS J., (1981), Theorie des kommunikativen Handelns, Frankfurt a/M, Suhrkamp.

HABERMAS J., (1988), Nachmetaphysisches Denken, Frankfurt a/M, Suhrkamp.

JOAS H., (1980), G. H. Mead: A Contemporary Re-examination of His Thought, Cambridge, Mass., MIT Press.

JOAS H., (1996), The Creativity of Action, Cambridge, Polity Press.

MILLER D. L., (1973), George H. Mead: Self, Language and the World, Chicago, University of Chicago

Press.

TAYLOR Ch., (1992), The Ethics of Authenticity, Cambridge, Mass., Harvard University Press

VICTOROFF D., (1953), G. H. Mead sociologue et philosophe, Paris, Vrin

\section{NOTES}

1. H. Blumer, Symbolic Interactionism: Perspective and Method, Berkeley, University of California Press 1969.

2. J. Habermas, Theorie des kommunikativen Handelns, Frankfurt a/M, Suhrkamp, 1981.

3. Especially Hans Joas' and David Miller's studies.

4. D. Victoroff, G.H. Mead sociologue et philosophe, Paris: Vrin 1953.

\section{AUTHORS}

\section{ANNA M. NIEDDU}

Universita di Cagliari

anieddu[at]unica.it 